\title{
Die relevansie van kerkreg met besondere verwysing na die Nederduitsch Hervormde Kerk van Afrika
}

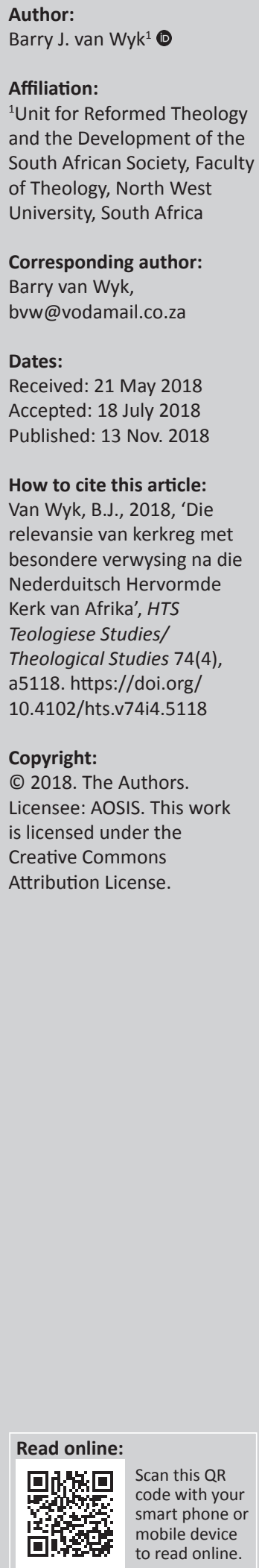

This article believes church polity is critically important, especially in recent times where an appeal is quite easily made to the courts of the political dispensation. The article believes the scriptural viewpoint that Jesus Christ is head of the church plays a substantial role in the modern-day church, which should be kept in mind regardless. Reference is made to court cases in the past and the conclusion is that church polity is relevant because it is a scriptural necessity.

\section{Inleiding}

Die artikel poog om andermaal 'n bydrae te lewer om die belang van kerkreg in die Nederduitsch Hervormde Kerk van Afrika te beklemtoon. In dié verband kan 'n mens nie anders as om te verwys na die historiese aanloop van kerkreg sedert die Hervorming nie, maar ook te wys op die genuanseerde betekenis van kerkreg en kerkorde met verwysing na bepaalde prinsipiële vertrekpunte. Die spanning wat soms tussen die kerklike reg en die reg wat in die burgerlike wetgewing ontstaan, word ook belig - nie net in die eie Kerk nie, maar ook in ander kerke. Ten slotte word 'n argument gevoer ten gunste van 'n herwaardering van kerkreg en kerkorde, asook die betekenis daarvan in Skriftuurlike lig.

\section{Historiese aanloop}

Kerkreg is eintlik sinoniem met die kerk, hetsy van Reformatoriese of van Rooms-Katolieke (vgl. Huysmans 1988) oorsprong. Toe Martin Luther op 10 Desember 1520 bepaalde geskrifte, insluitende die pouslike veroordeling Exsurge Domine van 15 Junie 1520, in die openbaar verbrand het (Brecht 1983:374), was daaronder ook 'n kopie van die Roomse kerkorde wat as die Corpus iuris canonici (vgl. Bakhuizen van den Brink, De Bruin \& Dankbaar 1965:93, 191) bekend gestaan het (Brecht 1983:403-406). Luther word gesensureer, wat opgevolg is deur die Decet Romanum Pontificem op 3 Januarie 1521 waardeur Luther geëkskommunikeer is (Denzinger 2012:363-367).

In die bul Unam Sanctam van 18 November 1302, het Pous Bonifatius VIII reeds die absolute aansprake van die Pous soos volg geformuleer (Denzinger 2012:287; vgl. De Jong 1987:124; Schaff 1890:58850, 58925; Van't Spijker 1990a:304): 'Porro subesse Romano Pontifici omni humanae creaturae declaramus, dicimus, definimus et pronuntiamus omnino de necessitate salutis' ['Futhermore we declare, state, and define that it is absolutely necessary for the salvation of all human creatures that they submit to the Roman pontiff'].

In dieselfde 'bul' is die sogenaamde leer van die twee swaarde (Luk 22:38; Matt 26:52), wat beide aan die kerk toekom, soos volg gestel (Denzinger 2012:287; vgl. Bouwman 1985:179; Weijland 1988:83): 'Uterque ergo est in potestate Ecclesiae, spiritualis scilicet gladius et materialis. Sed is quidem pro Ecclesia, ille vero ab Ecclesia exercendus' ['Both are therefore in the Church's power, that is, the spiritual sword and the material \{sword\}. But the latter is to be employed for the Church, the former by the Church']. Ook hier word die uitspraak gemaak dat geen verlossing of vergewing van sondes buite die kerk bestaan nie (Denzinger 2012:286; vgl. Graafland 1989:30): 'nosque hanc firmiter credimus et simpliciter confitemur, eztra quam nec salus est nec remissio peccatorum' ['and we firmly believe in her and sincerely confess her outside of whom there is neither salvation nor remissions of sins']:

De kerk was dus pauselijke kerk geworden. De paus is de bron van het kerkelijke dogma en van het kerkelijke recht, de eigenaar van het kerkegoed, het hoofd van den geheelen clerus. (Bouwman 1985:180)

Die gesag waarmee die Roomse Kerk, soos verwoord deur die Pous, funksioneer het en die betekenis wat gevolglik aan die Roomse kerkorde toegeken is, was anders as wat in Reformatoriese kerke geheers het en tot op hede geldig is. 
Dié absolute gesag het mutatis mutandis [met die nodige wysiging] ook vir die Roomse kerkorde gegeld en onderstreep waarom Luther se verbranding van die dokument as 'n besonder skerp vorm van protes gesien is. Die botsing tussen die Pous en Luther was wesenlik 'n botsing tussen twee teenoorstaande kerkbegrippe, maar kan ook tipeer word as twee kerkordes wat in die lig van die pouslike gesag verskillend in die praktyk waardeer is. Dié absolute en afdwingbare gesag het kerkordes in kerke van Reformatoriese oorsprong nie. In die lig van die feit dat die enigste hiërargiese moment in die kerkordelike gesag deur Jesus as Hoof van die kerk ingeneem word (Ef 1:22, 23), beteken dat die Pous van sy belangrike posisie by implikasie ontneem word. Derhalwe is daar geen hiërargiese moment in die kerkregtelike bestel van kerke van Reformatoriese inslag nie, behalwe die wesenlik Bybelse uitgangspunt dat Jesus Christus die Hoof van die kerk is. Noordmans (1984:396) het met gebruikmaking van die skaakbord skerpsinnig verwys na die verandering van die Pous se gesag sedert die Reformasie as hy stel dat toe Calvyn, die ouderling, as pion op die skaakbord geplaas het, die Pous daarmee in skaakmat geplaas is.

\section{Prinsipiële kerkordelike vertrekpunte}

Beklemtoning van die hoofskap van Christus verwoord 'n besonder belangrike uitgangspunt in kerkordes van Reformatoriese oorsprong, en kan as hermeneutiese sleutel beskou word wat aanduiding vorm van die oorsprong en bedoeling van 'n kerkorde as sodanig. Daarmee saam verwoord dié uitgangspunt ook 'n Skriftuurlike uitgangspunt (vgl. Ef 1:22-23) wat wesenlik is; nie net vir die kerkreg nie, maar ook vir die kerk in die algemeen (vgl. Van Wyk 2016). In dié sin is dit gepas om die ordemaatreëls wat kerkordelik geformuleer is as kerkorde te tipeer, en nie 'n kerkwet te noem nie en ook nie so toe te pas nie. Die benaming kerkorde geld in die Nederlandse tradisie sedert die Sinode van Middelburg 1581 (Jansen 1952:7). Die Heerskap van Christus is wesenlik vir wat genoem kan word 'n kerkordelike hermeneutiek (Le Roux du Plooy 2012; Van de Beek 1988) waardeur reg aan die bedoeling van 'n bepaalde kerkorde geskied.

'n Kerkorde word benader vanuit 'n bepaalde vooronderstelling wat wesenlik is vir die manier hoe die kerkorde toegepas word en is direk eweredig met die mate waarin 'n kerkorde nageleef word. Hermeneutiek is nie net van toepassing in die teologies-kerkordelike debat nie, maar kom ook voor in die uitleg van regstekste soos van toepassing in die burgerlike regspleging waar die geformuleerde reg en die praktyk met mekaar in verband gebring word. Kerkordelike hermeneutiek het egter 'n derde en bepalende moment toegevoeg, wat as 'hermeneutiese driehoek' beskryf is (Van de Beek 1988:62), naamlik die Skrif as normerende norm vir die kerklike lewe, wat bepalend meespreek in die verhouding tussen teks en toepassing in die kerklike lewe. Vorster (1992:91) het aangedui dat verantwoordelike kerkregering slegs moontlik is wanneer 'gesonde hermeneutiese reëls' toegepas word.
Van de Beek (1988:63-64; vgl. Koffeman 2009:95-96; Le Roux du Plooy 2012:6-7) onderskei kerkordelike hermeneutiek in verskillende fasette wat bruikbaar van toepassing gemaak kan word. Literêre hermeneutiek vra na die betekenis van 'n bepaalde formulering binne die breër konteks, terwyl strukturele hermeneutiek ' $\mathrm{n}$ bepaalde formulering oorweeg binne die geheel van die kerkorde. Historiese hermeneutiek dra daartoe by om te kyk na die historiese agtergrond waarbinne die formulering ontstaan het. Sistematiese hermeneutiek plaas 'n bepaalde formulering binne die teologiese tradisie van die kerk, en teleologiese hermeneutiek hou die doel van die formulering in gedagte waardeur die regsgevoel van die kerklike gemeenskap en die effek daarvan oorweeg word.

Historiese hermeneutiek as navraag na die funksionering van 'n kerkordelike formulering in historiese verband en ook as die Wirkungsgeschichte van 'n bepaalde kerkordelike regsreël bekend is, word ook tipeer as die reg van usansie op grond waarvan 'n sterk argument moontlik is tot kerkordelike genoegdoening. Hermeneuties moet ook afgegrens word teen uiterstes wat in die kerklike praktyk na vore kom, naamlik enersyds ' $n$ rigiede en onverbiddelike toepassing van 'n kerkordelike maatreël, teenoor andersyds ' $n$ totale negering van kerkordelike formulerings asof geen kerkorde bestaan nie. Beide verwoord 'n mate van onbevoegdheid of selfs onwilligheid om die kerkorde na waarde te skat.

Die eie aard van 'n kerkorde binne Reformatoriese konteks as 'n bundel wat die Skrif as agtergrond het, verg dus 'n hermeneutiese hantering van die kerkorde. Dié uitgangspunt onderskei 'n kerkorde van die konstitusie van 'n sosiale vereniging wat in soverre sy gesag gelyk is aan die somtotaal van sy lede. Ten spyte van die feit dat 'n kerkorde ook vasgestel word (soos gebruiklik) met meerderheid van stem onder leiding van die Heilige Gees (vgl. Noordmans 1990:390), is sinodale vergaderings nie altyd so eenstemmig as wat verwag sou word nie.

Die verhouding van 'n kerkorde tot die Skrif en die implikasie wat sodoende kerkregtelik teweeggebring word as 'n sogenaamde Skriftuurlike kerkorde wat uit dié noue verhouding volg, kan as 'n dialektiese verhouding bestempel word. Skriftuurlikheid van 'n kerkorde beteken nie dat elke formulering reglynig deur 'n bepaalde Bybelse uitspraak ondersteun word nie, maar insgelyks beteken dit ook nie dat 'n kerkorde geen Skriftuurlike basis het nie. In dié verband word die vraag gedebatteer of 'n kerkorde ius divinum [goddelike reg] of ius humanum [menslike reg] is (vgl. Koffeman 2009:90; Van Wyk 1991:44-55). Dialekties beskou, waarskynlik nie gelyk aan enigeen van beide nie en waarskynlik is dit bruikbaar om 'n kerkorde as ius humanum te beskou met die harde kern van die ius divinum (vgl. Van Ruler 1952:90) wat 'n kerkorde van die konstitusie van 'n vereniging onderskei. Vleeswording van die Woord impliseer dat die reg van God gestalte aanneem in menslike reg en tot gevolg het dat Goddelike reg redelik menslik daar uitsien (vgl. Van't Spijker 1972:6). Barth (1964:808) is van mening dat die 'ius divinum der Christokratie wie als seinen Ursprung, so 
auch als seine Grenze im Auge behalten, sich selbst also in aller Strenge als ius humanum verstehen'.

Die besondere verbinding aan die Skrif en die Skriftuurlike basis van 'n kerkorde beteken dat 'n kerkorde ook as ekklesiologie in praktyk gesien kan word. In dié verband is die Dingemans (1988:207) uitspraak dat 'n kerkorde in regsreëls vertaalde ekklesiologie is - oorbekend maar tog bruikbaar. Sedert die ekklesiologiese debat vorm aangeneem het - en met besondere verwysing na die debat hedendaags - word 'n kerkorde en sy inhoud sterker in die sentrum geplaas as 'n bepaalde kerk se siening van homself in Bybelse lig - of anders gestel: hoedanig die ekklesiologie van 'n bepaalde kerk kerkordelik daar uitsien. Ekklesiologie word sterk aan missionaal gebind en daar is selfs sprake van missionale ekklesiologie (Dreyer 2013) en missionale teologie (Van der Merwe 2011:6). Die uitgangspunt dat missionaal spruit uit missio Dei en gesien word as die sending van God aan die wêreld waaraan die kerk die voorreg het om mee te doen, nie as een faset van kerklike werk nie, maar as uiting van die wesenlike van kerkwees en daarom allesomvattend, is verdienstelik (Bosch 2005:390). Die standpunt dat missionaal deur ekklesiologie en ekklesiologie Christologies bepaal word, dui daarop dat missionaal werklik tot sy reg kom as 'n uiting van 'n Christologiese ekklesiologie (vgl. Van Wyk 2017:3). Dié beklemtoning geld nie net missionaal nie, maar eweneens vir die kerkorde wat volledig inpas in die mees basiese bron vir die kerkorde en die kerkreg, naamlik die Skrif (Coertzen 1991:121-122; vgl. Van't Spijker 1990c:327).

Meegaande beklemtoning in missionale en kerkregtelike verband is wesenlik vir die kerk, aangesien die hoofskap van Christus as die enigste manier om vreesloos die toekoms te benader sodoende bevestig word as roepende en bemoedigende getuienis om inderdaad missionaal en volgens kerkorde, kerklik te leef. Die Skriftuurlike uitspraak en belydenis dat Jesus Christus Hoof van die kerk is (vgl. Van der Walt 1976) kom telkens terug en geld ongekwalifiseerd vir alle kerklike handelinge - selfs nog meer omvattend, naamlik vir die kerk as geheel in al sy geledinge en derhalwe ook kerkordelik. Dit kan dus nie anders nie as dat die kerkorde van 'n kerk van Reformatoriese oorsprong voortdurend Skriftuurlik bepaal en uitgelê moet word. Dit geld ook onverkort vir die hantering van 'n kerkorde wat geskied deur ampsdraers en lidmate in vergaderings van die ampte, maar ook in broederlike verband. Broederlik in die verband as tegniese spreekwyse vir die gesprek tussen lidmaat en lidmaat, wat ampsdraers insluit as 'n gesprek in Skriftuurlike lig (Ordinansie 8.1, NHKA 2016:84).

Met verloop van tyd ontstaan die tegniese vraag hoe die kerkorde funksioneer en in watter mate kerkordelike maatreëls nageleef word. In die lig van die gesaghebbende gesag van die Skrif, is 'n kerkorde eintlik oorbodig en moet dit as't ware tot ' $n$ minimum beperk word. Dieselfde sou ook ten opsigte van belydenisskrifte gesê kon word. Die geformuleerde belydenisskrifte waaroor wye konsensus in kerklik ekumeniese verband bestaan, asook kerkordes wat sedert die Reformasie die lig gesien het, dui daarop dat die
Skrif tog verklaar moet word as uiting oor hoe die Skrif deur sinodale vergaderings verstaan en uitgelê word in belydende en kerkordelike verband. Eweneens geld dit vir 'n bestaande kerkorde op enige gegewe moment in ' $n$ bepaalde kerk as noodsaaklike ordemaatreël vir die gang van kerklike welwese. Die verwagting dat almal op grond van die mees wesenlike Skriftuurlike uitgangspunt dat Jesus Christus die Hoof (Ef 1:22, 23) van die kerk is en daarom eenstemmig sal praat en ordelik handel, is nie noodwendig so nie. Daarvan getuig kerklike afskeidings en dissiplinêre handelinge. Onderskeid moet gemaak word tussen uiting gee aan Christus se hoofskap, en andersyds hoe kerkordelike strukture en ampsdraers so prominent funksioneer dat daardeur ' $n$ kerkordelike hiërargie gevestig word.

In dié verband word verwys na Episcopalisme, waarvan die Roomse Kerk as voorbeeld dien. Die Biskop van die Kerk van Rome tree op grond van die toegekende gesag aan Petrus (Matt 16:18) as plaasbekleër van Christus op. Sy gesag geld vir die hele kerk en kragtens sy amp is sy gesag 'de hoogste, volledige, onmiddellijke en universele gewone macht in de Kerk, die hij altijd vrij kan uitoefenen' (Van't Spijker 1990a:305; vgl. Weijland 1988).

Daarnaas ook kongregasionalisme of independentisme - twee begrippe wat naas mekaar gebruik word as aanduiding dat die gemeente selfstandig funksioneer en nie afhanklik is van 'n biskop of 'n sinode nie, aangesien die gemeente draer van alle gesag is (Van't Spijker 1990b:313; vgl. Deddens 1988:106109; Van der Linde 1965:80; Van der Walt 1976:18).

Die bestaan van die rotasiebeginsel en die tweejarige ampstermyn van ouderlinge en diakens (Artikel XV) ${ }^{1}$ (Kersten 1980:44) het iets verraai van die moontlikheid dat, ten spyte van die besondere Skriftuurlike uitgangspunt waaruit 'n kerkorde funksioneer, die moontlikheid van bepaalde uitwasse in die kerkregtelike bestel nie denkbeeldig was (is) nie.

In dié verband het die Nederlandse kerkordes ook bepaal dat die ampstermyn van 'n sinodale voorsitter eindig na afloop van die vergadering. Die Sinode van Emden formuleer '[p]raesidis officium cum actione finitur ... Des praesidents ampt neemt een einde met het einde der Synodi' (Rutgers 1980:111-112) en verskyn ook in die kerkorde wat tydens die Dordtse Sinode van 1618-1619 vasgestel is, wat 'n bepaalde afsluiting vorm vir die kerkregtelike ontwikkeling in Nederland sedert die Konvent van Wezel 1568² (Kersten 1980:184). Die bedoeling was, soos reeds sedert Emden vasgestel is, 'dat Emden het levenslang dienen van de ambtsdragers verworpen heeft om elke nieuwe tirannie en elk clericalisme te vermijden' (Hovius 1972:19).

Daarom ook in die eerste artikel die geformuleerde antihiërargiese beginsel dat geen 'kerk zal over een andere kerk, geen

1.Acta of Handelingen der verzameling van de Nederlandse kerken die onder het Kruis zitten, en in Duitsland en Oost-Friesland verstrooid zijn, gehouden te Embden, de 4de Oktober 1571 (Kersten 1980:41).

2.Kerkordening gesteld in de Nationale Synode der Gereformeerde Kerken, tezamengeroepen en gehouden door orde van die Hoogmogende Heren Statentezamengeroepen en gehouden door orde van die Hoogmogende Heren StatenArt. XXXV. 
dienaar des Woords, geen ouderling, noch diakenen, zal de een over de ander heerschappij voeren' (Kersten 1980:41; vgl. Plomp 1971:89). Die kerkorde van Emden word ook afgesluit met artikel LIII wat as die anti-independentistiese beginsel beskryf word en beteken dat 'n kerk (gemeente) die orde wat met 'gemeen akkoord' vasgestel is, saam met 'alle kerken zullen arbeiden deze te onderhouden, totdat in een synodale vergadering anders besloten wordt' (Kersten 1980:53). Beide uitgangspunte het mekaar goed aangevul. 'Wie alleen oog heeft voor het gevaar van de hiërarchie vervalt gemakkelijk tot independentisme. Omgekeerd: wie alleen beducht is voor independentisme, heeft nauwelijks verweer tegen de hiërargie' (Plomp 1971:90).

Dit is wyd bekend dat die kerkregtelike stelsel wat sodoende ontstaan het as presbiteriaal-sinodaal tipeer word (vgl. Bronkhorst 1947:258; Van't Spijker 1990c:326-338), wat wesenlik en bondig beteken dat Jesus Christus Hoof van die kerk is (Plomp 1967:7; Post 2003:23; Smit 1984:75; Van't Spijker 1990c:326). Dit is só tot op hede, ten spyte van klemverskille, en daarom kom die vraag ter tafel na die stand van die kerkreg in hedendaagse kerke, met besondere verwysing na die Nederduitsch Hervormde Kerk van Afrika (NHKA), asook ander sogenaamde hoofstroomkerke in Suid-Afrika.

In die Suid-Afrikaanse kerkregtelike debat het dit gemeengoed geword om die Nederlandse Algemeen Reglement van 1816 as kollegialisties te beskou (vgl. De Wet 1921; Kuyper 1884:51-52). Daarom is die Algemeen Reglement van die Kaapse Kerk van 1824 ook kollegialisties en die kerkorde van die Nederduitsch Hervormde Kerk van Afrika by implikasie ook kollegialisties (Pont 1991:110; vgl. Van Wyk 1991:112-122). Pont (1991:120-126; vgl. OostenbrinkEvers 2000:30; Van't Spijker 1992:996) het aangedui dat die Algemeen Reglement van 1816 nie onder invloed van die kollegialisme tot stand kom nie, maar dat J.D. Janssen, 'n regeringsamptenaar, die geestelike vader van die Reglement was wat nie onder die invloed van die kollegialisme was nie. Dit is inderdaad duidelik dat kollegialisme nie die basis vorm op grond waarvan die kerkordelike struktuur van die Hervormde Kerk gebaseer is nie indien kollegialisme gesien word as die:

... hallmark of Collegialism is that church government finds its point of orientation not in Scripture, but in state government. ... in its essence democratic (vox populi vox dei) ... a form of oligarchy executed by permanently elected functionaries of the church ... the synod becomes known as the church, or as it is sometimes expressed, the synod as the sum total of the different congregations. (Smit 2018:3)

'n Sinodale vergadering wat bindende besluite neem wat oor 'n kerk as geheel geldig is, deur ampsdraers wat daarheen afgevaardig is, beteken nie dat die kollegialisme die botoon voer nie, want kerklike vergaderings neem besluite nie anders as op grond van die Skrif en onder leiding van die Heilige Gees nie. In dié opsig staan 'n kerkraadsvergadering en 'n sinodale vergadering op gelyke voet. Dit is Du Plooy (2008:427) se standpunt wat ratifikasie van sinodale besluite deur kerkrade afwys, omdat beide vergaderings nie in ' $n$ dualistiese verhouding staan nie, en aanvaar dat besluite daar ook op grond van die Skrif, die belydenis en die kerkorde geneem word.

Behalwe vir bogenoemde het die Nederlandse Hervormde Kerk (NHK) weerstand gebied teen die Algemeen Reglement van 1816 en daarin geslaag om op 01 Mei 1951 (Van den Heuvel 1991:17; vgl. Oostenbrink-Evers 2000:15) 'n kerkorde in gebruik te neem wat radikaal van die Algemeen Reglement van 1816 verskil het. Dis eweneens merkwaardig dat as die Nederlandse Hervormde Kerk, die Gereformeerde Kerken in Nederland en die Evangelisch-Lutherse Kerk saamsmelt op 01 Mei 2004 om die Protestantse Kerk in Nederland (PKN) te vorm, die samesmelting, soos verwoord in die kerkorde van die PKN (PKN 2004), geskied op die kerkorde van die Nederlandse Hervormde Kerk van 1951. Ook dit is begryplik aangesien teoloë van die Nederlandse Hervormde Kerk wat aan die 1951 kerkorde gewerk het, doelbewus besluit het om nie van die Dordtse kerkorde van 1618-1619 gebruik te maak nie vanweë die na binne gerigtheid van die kerkorde en die patronaatsreg (invloed van die owerheid wat selfs kerkregtelik gereël was) wat in die Dordtse kerkorde verwoord is (Balke \& Oostenbrink-Evers 1993:XXXIX).

Die 1951 kerkorde van die Nederlandse Hervormde Kerk is ook die kerkorde wat gebruik is in die formulering van die kerkordelike maatreëls wat sedertdien in die Nederduitsch Hervormde Kerk van Afrika mutatis mutandis in gebruik is (Van Wyk 1991:171-174).

Die kerkorde van Dordt 1618-1619 is ook in Gereformeerde kringe in Suid-Afrika aangepas deur die verwydering van die patronaatsreg as aanduiding van die feit dat die Dordtse kerkorde nie sonder meer bruikbaar is in die hedendaagse konteks nie. Dat Dordt 1618-1619 in 'n sekere sin die afloop vorm van die Nederlandse kerkregtelike debat sedert Emden 1571, beteken nie dat Dordt die skeiding vorm tussen kerkregtelik-ortodoks en kerkregtelik-vrysinnig nie. Want die vraag is of 'n kerkorde aan die wesenlike uitgangspunt voldoen, naamlik die Hoof- en Heerskap van Christus. Dit sou merkwaardig wees as 'n kerkorde dit wel verwoord, maar tog uitsluitlik leef onder die vaandel van die meerderheid van stem in vergaderings wat met Woordbediening geopen en gesluit word.

\section{Die Nederduitsch Hervormde Kerk van Afrika}

Formeel gesproke kan sekerlik met dank geboekstaaf word dat elkeen van die sogenaamde hoofstroomkerke steeds oor 'n kerkorde beskik. Die Nederduitsch Hervormde Kerk van Afrika (NHKA) het tydens die een-en-sewentigste Algemene Kerkvergadering (2016) 'n kerkorde vasgestel wat hersien en aangepas is om uiting te gee aan die veranderde omstandighede waarin kerke tans kerk moet wees (NHKA 20163).

In dié kerkorde kom die hoofskap van Christus pertinent ter sprake in Ordereël 4, asook in Ordereël 8 (NHKA 2016:42, 82).

3.Alle kerkordelike verwysings is uit die kerkorde wat tydens die 71 e Algemene Kerkvergadering (NHKA 2016) vasgestel is, tensy anders vermeld. 
Verder is die anti-hiërargiese uitgangspunt behou met die formulering dat die 'een vergadering heers nie oor die ander, die een amp nie oor die ander en die een ampsdraer nie oor die ander nie' (Ordereël 4, NHKA 2016:42). Verder word ook die anti-independentistiese uitgangspunt in die kerkorde teruggevind, met die formulering dat die Algemene Kerkvergadering se besluite namens alle gemeentes, ampsdraers en lidmate (Ordinansie 4.4.3 (i), NHKA 2016) bindend is vanaf die oomblik waarop dit geneem is, tensy die vergadering anders besluit (Ordinansie 4.4.4 [xviii], NHKA 2016). Rotasie is ook behou, al is dit beperk tot ringsvergaderings (Ordinansie 4.2.3 [x] en [xii], NHKA 2016:52) en die Algemene Kerkvergadering (Ordinansie 4.4.4 [vii], NHKA 2016).

In Ordereël 1 word belydend verklaar dat die Nederduitsch Hervormde Kerk se geloof gegrond is in die Drie-enige God, Vader, Seun en Heilige Gees, ooreenkomstig sy Woord, die Bybel, saam met die kerk van alle eeue soos geformuleer in die ekumeniese en reformatoriese belydenisskrifte (NHKA 2016:1). Derhalwe word van predikante verwag om die proponentsformule te onderteken (Ordinansie 1.1.2; Ordinansie 3, NHKA 2016:3, 20), wat op die quia-standpunt geskied as belydenisskrifte wat gehandhaaf word omdat die inhoud in ooreenstemming met die Skrif is. Daarmee is nie uitgesluit nie dat belydenisskrifte dateer uit die sestiende eeu, en die ekumeniese belydenisskrifte selfs ouer is en daarom hermeneuties gelees en gebruik moet word. Die Kerk verander ook nie aan die belydenisskrifte nie (Ordinansie 1.3.1, NHKA 2016:3), sonder om daarmee te kenne te gee dat belydenisskrifte en die Woord op dieselfde vlak te staan gekom het.

Die feit dat kerkordelike maatreëls as kerkorde bekend staan en die klem op orde rus, gesien in die lig van die Skrif en belydenisskrifte as hermeneutiese agtergrond waarteen ' $n$ kerkorde funksioneer en waardeer moet word, sou dit verwag kon word dat erns met die kerk erns met die Skrif beteken, en gevolglik ook erns om kerkordelik in die kerk te leef en op te tree.

Die kerklike praktyk toon egter aan dat nie noodwendig daaraan voldoen word nie en bevestig dat 'n kerkorde aan kerkordelike verwagtings mag voldoen, maar indien nie daarvolgens geleef word nie, dit irrelevant word - of 'n kerk oor 'n kerkorde beskik al dan nie. Krities beskou, geld dieselfde ook vir die Skrif as Gods Woord. Die kerklike verlede toon aan dat kerkordelike maatreëls óf negeer word óf alternatiewelik 'n beroep gedoen word op die burgerlike regspleging teen kerklike maatreëls. 'n Geringskatting van kerkordelike maatreëls kan as 'n hedendaagse vorm van independentisme beskryf word, wat daarop neerkom dat ampsdraers en kerkrade eiesinnig handel sonder 'n sensitiewe kerkordelike bewussyn. 'n Beroep op die burgerlike howe om interne kerklike verskille op te los, kom dus neer op 'n na-buite-gerigte independentisme, aangesien verwag word dat kerklike moontlikhede eers benut sal word om geskille uit die weg te ruim, alvorens 'n beroep op die wêreldlike hof gedoen word (Ordereël 8.3.3, NHKA 2016:82). 'n Beroep op die burgerlike gesagstrukture, soos howe, is waarskynlik een van die grofste vergrype teen die besondere aard van 'n kerkorde.

Dié hedendaagse neiging om geskille wat in kerke ontstaan in howe te laat besleg, is seker een van die grofste miskennings van 'n kerkorde. Sodoende egter, word die vraag na kerkordelike relevansie sterk op die tafel geplaas. 'n Kerkorde verwys na Christus (vgl. Joh 3:30). Dit gee sin aan 'n kerkorde en grens terselfdertyd die kerk af teen die burgerlike regspleging. Die hedendaagse beroep op die burgerlike regspleging om kerklike (kerkordelike) geskille aan te hoor, is nie net tot die onlangse verlede beperk nie. Die argument kan teruggevoer word tot die uiteindelike beroep van die apostel Paulus op die Romeinse Keiser (Hand 25:11), ten spyte van die feit dat hy hofsake onder medegelowiges afgekeur het (1 Kor 6:4-6). Dit is waarskynlik waarskuwend van aard vir kerke en gelowiges om in die kerk só op te tree en te leef dat 'n beroep op 'n wêreldlike hof nie nodig is nie. Kerklike optrede wat in 'n wêreldlike hof gekorrigeer moet word, is niks minder as 'n growwe kerklike verleentheid nie. Daarmee saam is dit onkerklik om 'n beroep op 'n wêreldlike hof te doen sonder meer met verbygaan van kerklike opsighandelinge. Die Skriftuurlike binding van betrokkenes behoort sodanig van aard te wees dat geskille deur broederlike gesprekke opgelos word (Van Wyk 2008:1129). Ten oorvloede word daarop gewys dat die burgerlike wetgewing nie die agtergrond is waarteen 'n kerkorde verstaan en uitgelê moet word nie. Reg en reg in beide verbande is nie aan mekaar gelyk nie.

Naas regsaksies in ander kerke het die Nederduitsch Hervormde Kerk ook met die regspleging in kerklike aangeleenthede te make gehad. Die mees bekende uit die historiese verlede waardeur die Kerk se voortbestaan bestendig is, was die Trichardtsfontein saak wat oor kerklike eiendomme ontstaan het na aanleiding van die mislukte kerkvereniging van 1885. Die hof het op 05 Junie 1893 beslis dat die besluit van die Algemene Kerkvergadering om te verenig ultra vires was op grond van die feit dat die kerk 'n universitas [sedelike liggaam] is en nie 'n societas [vennootskap of maatskappy] nie, wat daarop neerkom dat 'n kerk slegs met toestemming van ál sy lede opgehef kan word (Engelbrecht 1953:349; vgl. Coertzen 2001:117; Post 2003:236-237).

In die Nederduitse Gereformeerde Kerk (NGK) se geledere het, ná die besluit op 14 April 1994 dat die Nederduitse Gereformeerde Kerk in Afrika (NGKA) en die Nederduitse Gereformeerde Sendingkerk (NGSK) verenig om die Verenigende Gereformeerde Kerk in Suid-Afrika (VGK) te vorm, ook 'n hofgeding ontstaan. Vanuit die VGK word 'n aansoek na die Hooggeregshof van die Vrystaat gebring dat die NGKA opgehou het om te bestaan sedert die vereniging plaasgevind het op 14 April 1994 (Coertzen 2002:388; Post 2003:238). Die VGK was aanvanklik suksesvol aangesien die Hooggeregshof die VGK toegegee het (Hooggeregshof van Suid-Afrika, 05 September 1996, Saaknommer:799/96;vgl. Post 2003:239). 
Die beslissing is op appèl geneem en die bevinding was dat 'n algemene sinode se inherente bevoegdheid nie die reg insluit om sonder die goedkeuring van al sy lede (gemeentes) die kerkverband te verander en 'n ander kerk te stig nie. Die streeksinodes en gemeentes wat daarby ingesluit is, het die reg op eie kerklike goedere behou en kon nie gedwing word om dit aan 'n verenigde kerk af te staan nie (Hoogste Hof van Appèl van Suid-Afrika, 27 November 1998, Saaknommer 536/96; vgl. Post 2003:240). Hier kan verder ook onder andere verwys word na die Kotze-saak (1864), die Du Plessis-saak (1931), asook die Schreuder-saak (1999) waarin die NGK betrokke was (Scholtz 2001:184,186).

'n Hofgeding wat minder gunstig vir die Hervormde Kerk (NHKA) verloop het, ten minste terugskouend beoordeel, is die saak tussen die Kerk en prof A.S. Geyser. Van die klag wat uit 20 onderdele bestaan het, is hy slegs op een skuldig bevind met betrekking tot sy eksegese van Filippense 2:6-11, in 'n verhoor deur die Kommissie van die Algemene Kerkvergadering wat op 08 Mei 1962 die bevinding bekend gemaak het (Dreyer 2016:7). Die saak het 'n onaangename nadraai beleef in die Hooggeregshof toe die saak op 15 Mei 1963 ten einde geloop het met 'n erkenning deur die Kommissie van die Algemene Kerkvergadering dat gefouteer is met die skuldigbevinding en dat prof Geyser in sy pos as professor herstel word, asook dat die Kerk alle regskoste van die saak sou betaal (Dreyer 2016:9). Die saak se laaste nadraai was in die lastereis (1968) teen prof A.D. Pont deur prof A.S. Geyser en ds. Beyers Naude waarin Pont skuldig bevind is.

Die relevansie van kerkreg in die kerk word waarskynlik nog beter geïllustreer in die hangende hofgeding wat sedert die nege-en-sestigste Algemene Kerkvergadering (2010) ontstaan het met die verklaring oor apartheid; beskrywingspunt 54 (NHKA 2010a:108). Die onmiddellike gevolg van die aanvaarding van die beskrywingspunt was kerklike skeuring en gemeentes wat hulleself as die 'steedsHervormers' in 'n geloofsbond georganiseer het. Dit het ook daarop uitgeloop dat aanspraak gemaak is op gemeentelike eiendomme en oordrag daarvan, onder die indruk dat dit 'n gemeente vrystaan om met meerderheid van stem van die NHKA af te skei - dit ook in die lig van sogenaamde restitusie eise wat die Kerk sou bedreig het in die lig van die Kerk se verklaring oor apartheid.

Die optrede van die sogenaamde 'steedsHervormers' dui op 'n persepsie in kontras met die kerkordelike formulering en siening van hoe die Kerk homself sien. Daar is slegs één Hervormde Kerk, wat 'n gemeenskap van gelowiges is wat selfstandig georganiseer is in gemeentes wat saam met al die ander gemeentes die somtotaal, dus gelyk, is aan die één Nederduitsch Hervormde Kerk (Ordereël 4, NHKA 2010b:65). ${ }^{4}$ Lidmaatskap van die Kerk is diegene wat deur God in genade geroep is en deur die Heilige Gees in Jesus Christus glo (NHKA 2010b:65). Die Hervormde Kerk is dus

4.Kerkordelike verwysings met betrekking tot die steedsHervormers is uit die kerkorde wat tydens die nege-en-sestigste Algemene Kerkvergadering (2010) vasgestel is en gegeld het toe die skeuring plaasgevind het. nie 'n kerk wat uit gemeentes bestaan wat op grond van 'n kerkverband deel van die Kerk geword het en op dieselfde gronde die Kerk weer verlaat om deel te word van 'n ander kerkverband nie. Lidmaatskap van die Kerk is nie per gemeente nie, maar as individuele gelowige wat tot die één Kerk toetree, wat vir praktiese redes in gemeentes georganiseer is. Gemeentes is dus ecclesia completa et incompleta. Daar is ' $\mathrm{n}$ wisselwerking tussen gemeente en sinode wat beide ín een kerk en ás een kerk bestaan.

Die bevoegdheid van 'n gemeentevergadering om met meerderheid van stem oor die beskikking, aanskaf of vervreemding van vaste eiendomme te handel (Ordinansie 4.4.2 [vi)], NHKA 2010b:69), is tot die beswil van die Kerk en nie in diens van die afkeur van sinodale besluite nie. In dieselfde werkopdrag van 'n gemeentevergadering, word verwag dat toegesien word dat vaste eiendom in die naam van die gemeente geregistreer word (Ordinansie 4.4.2 [viii], NHKA 2010b:69). Dit is ook deel van die werkopdrag van kerkrade om vaste bates van die gemeente te administreer, te registreer en te verseker (Ordinansie 3.3.2 [ix] [g)], NHKA 2010b:43). Daarmee saam word ook van kerkrade verwag om skriftelike advies in te win vanaf die ringsvergadering en die Raad van Finansies (vgl. Ordinansie 3.3.2 [xvii]; Ordinansie 9.2.2.4 [iv], NHKA 2010b:44, 104), wat aan die gemeentevergadering voorgelê word alvorens magtiging verleen word om eiendom te koop, te vervreem, 'n gebou op te rig, of te sloop, en die besluit tot uitvoering deur die gemeentevergadering geneem word (Ordinansie 3.3.2 [xvii], NHKA 2010b:44). Behalwe hiervoor het die kerkorde net voorsiening gemaak vir twee gebeurlikhede waaronder 'n gemeente se bestaan opgehef word, naamlik by samesmelting (Ordinansie 4.7) en ontbinding (Ordinansie 4.8, NHKA 2010b:72-74). Hierdie reëlings is met die herskrywing van die kerkorde in 2016 behou.

Die strategie om as gemeente van die Hervormde Kerk af te skei, beslag te lê op die eiendomme en arbitrêr by die kantoor van aktes te registreer, was dus kerkordelik 'n ultra vires handeling waaroor die burgerlike regspleging ' $n$ oordeel in die toekoms moet vel. Pogings om die geskil by te lê, soos deur die Bemiddelingskomitee (NHKA 2013:154) en die buitengewone Algemene Kerkvergadering op 04 en 05 Oktober 2011, was nie suksesvol nie (NHKA 2013:152). Die Kommissie van die Algemene Kerkvergadering wat tydens die nege-en-sestigste Algemene Kerkvergadering verkies is, het oor die termyn 2010-2013 opgemerk dat, in die geskiedenis van die Nederduitsch Hervormde Kerk, dié periode voorwaar gereken kan word as een waarin die kerkorde op 'n spesifieke wyse op die voorgrond getree het (NHKA 2013:143).

Dit is ironies dat kerklike skeuring die besondere aard van die kerklike reg en die kerkorde moet belig en in perspektief stel om op sodanige manier, hoe negatief ook al, die relevansie van die kerklike reg te beklemtoon. 'n Kerk hoort nie tuis in 'n burgerlike geregshof nie, aangesien die kerklike reg ius in sacra is, terwyl die burgerlike wetgewing ius circa sacra is. Die neiging om die kerk as 'n sosiale vereniging te beskou, kom 
ook uit die kollegiale kerkreg, en van daaruit ontstaan die siening dat kerklike geskille deur die burgerlike regspleging bygelê moet word. Kerklike reg is ius sui generis - reg eie aan die aard van die kerk (vgl. Pont 1981:5). Gesien in die lig van die feit dat die bewoonde wêreld die werkplek van die kerk is, vorm dit 'n verleentheid wanneer kerklike geskille voor die diskresie van 'n regter van die burgerlike geregshof beland. Sodoende kom dit daarop neer dat 'n kerklike aangeleentheid uit die hermeneutiese driehoek wat in die kerklike reg geld (vgl. Van de Beek 1988:62), uitgehaal word en vanuit die hoek van die burgerlike wetgewing beskou word as 'n spanning tussen die geformuleerde regsreël en die praktyk. In dié opsig verword die kerk tot net nog 'n sosiale vereniging met' $n$ konstitusie, en die taak van die voorsittende beampte word dus simplisties gesien net om vas te stel of dié sosiale vereniging (die kerk) getrou was aan sy 'konstitusie' wat met meerderheid van stem deur sy lede vasgestel is. In dié situasie word 'n kerkorde deur die burgerlike reg as 'n kontrak beskou en die kerkraad die werkgewer van 'n predikant, om in te pas in die beroep op die arbeidswet, aangesien die kerklike reg nie noodwendig in burgerlike howe tot sy reg kom nie (vgl. Coertzen 2002:383).

Spore van die situasie waarin die Kerk leef en in verband met die neiging om 'n beroep op die burgerlike wetgewing te doen, word in die kerkorde aangetref wanneer in die beroepsbrief, in gedeelte twee wat oor versorgingsvoordele handel, aangedui word dat sover dit regtens nodig mag wees, is die gemeente die werkgewer van die predikant en vorm die beroepsbrief en die kerkorde van die Nederduitsch Hervormde Kerk 'n kontrak tussen predikant en gemeente. Dat oor die inhoud verskil van mening kan ontstaan wat dan in howe kan beland, word aan die einde van die versorgingsvoordele gestel dat enige handeling wat kragtens die kerkorde deur enige persoon of liggaam verrig is, sal geag word namens die gemeente en werkgewer verrig is (Beroepsbrief: versorgingsvoordele, 10.1, 10.2, 10.4, NHKA 2016).

Verder, indien 'n lidmaat of ampsdraer tog 'n beroep op 'n wêreldlike instansie doen om onderlinge geskille uit die weg te ruim sonder om die kerklike weg volledig te volg en daaruit ' $n$ regsgeding ontstaan, sal die lidmaat of ampsdraer aanspreeklik gehou word vir die Kerk se regskoste 'op 'n prokureur-kliënt skaal' (Ordinansie 8.1.5, NHKA 2016:86).

Derdens kan die kerkordelike formulering oor hoe 'n tugverhoor moet plaasvind, gesien word as 'n aanduiding van presiesheid om die Kerk te beskerm indien enige regshandeling daaruit sou volg. In dié verband volg die Kerk die reëls van natuurlike geregtigheid, soos die audi alteram partem [hoor die ander kant van die saak] beginsel wat ook as die Nikodemus-alternatief beskou kan word (Joh 7:51; vgl. Smit 1995:399-400), asook die feit dat niemand regter in sy eie saak is nie (nemo iudex in propria causa; vgl. Van Wyk 2004:263).

Kerklike optrede, ook kerkregtelike handelinge, wil inderdaad uiting gee aan die vindplaas en dryfveer van alle kerklike optrede, naamlik om kerk van die Woord te wees.
Daarom sou dit absurd wees indien kerkordelike maatreëls in ' $n$ kerkorde opgeneem is wat in stryd is met burgerlike wetgewing en waardeur die kerk uiteindelik deur ' $n$ regter van 'n wêreldlike hof gekorrigeer moet word. Die situasie kan ontstaan dat die kerk 'n kritiese woord moet spreek oor die owerheid en regspleging van die dag, aangesien die Skrif nie net ' $n$ kerklike (kerkordelike) maatstaf is nie, maar ook vir die owerheid en sy regspleging geld, ongeag of die owerheid sogenaamd neutraal is.

Dit is verder opvallend hoe maklik die weg gevolg word om 'n beroep op die wêreldse reg, met besondere verwysing na die arbeidsreg, gedoen word om geskille uit die weg te ruim, veral as vergoeding of verlof van predikante ter sprake is.

Dit is sekerlik onafwendbaar dat die wêreld waarin die kerk hom bevind - met besondere verwysing na die regsmilieu na die kerk op 'n bepaalde manier kyk, en oor die kerk vanuit sodanige hoek oordeel wanneer kerklike sake en veral kerklike verskille deur geregshowe besleg moet word. Appèlregter Harms het in sy uitspraak oor die saak (Saaknommer 536/96) tussen die NGKA en die VGK aangedui dat geloofskwessies nie vir geregshowe bedoel is nie, maar as kerke hulle tot geregshowe wend, moet algemene burgerlike beginsels aangewend word, soos wat geldig is by ander vrywillige verenigings, waarby kontrakbeginsels ingesluit is. In dieselfde uitspraak het appèlregter Hefer ook daarop gewys dat kerke vrywillige verenigings is waarvan die lede kontraktueel gebind word deur die betrokke kerkordes (vgl. Coertzen 2001:122). Dit kom daarop neer dat as 'n kerkorgaan buite sy bevoegdheid handel, is die burgerlike hof verplig om die handeling tersyde te stel. Dan is teologiese, kerklike, politieke en praktiese oorwegings onsaaklik.

In dieselfde uitspraak meld regter Harms ook dat eensgesindheid binne dieselfde kerk ook nie so volop is as wat van 'n kerk verwag sou word nie. Wanneer 'n regter dit stel, behoort dit vir kerke rede tot ernstige nadenke te dien en tot voorneme lei om kerk te wees, dit wil sê kerk van die Woord.

\section{Slotsom}

Die verhouding tussen howe en kerke, tussen reg en kerkreg, beklemtoon die vraag na die relevansie van die kerklike reg wat geldend is in kerke - veral kerke van Reformatoriese oorsprong. Die mate waarin gevra word na kerkreg en die betekenis van die kerkreg, is direk eweredig met die situasie wat in die burgerlike praktyk ontstaan het in soverre uitleg en bystand aan betrokkenes ter sprake kom. Goedgeaarde landsburgers is bewus van die reg in die vorm van howe, funksionarisse eie aan regspleging en die geformuleerde reg wat deur howe toegepas word. Normaalweg beland diesulkes wat dikwels ook lidmate van kerke is, nooit in howe nie en vra nie na bystand van regspraktisyns nie.

Iets daarvan is ook in die kerk waarneembaar. Kerkreg het die belangstelling van enkeles geword of wanneer 
'n noodsituasie in die kerk ontstaan wat die kerkreg ter sprake bring. In die Hervormde Kerk is die Kommissie van die Algemene Kerkvergadering (Kommissie) daarvoor verantwoordelik om die reg uit te lê wat bindend is op ampsdraers en lidmate (Ordinansie 4.6.2 [ix], NHKA 2016:58). In dié verband kan ook verwys word na die Raad vir Kerkregtelike Advies (Ordinansie 4.4.4 [xii] [d], NHKA 2016:54) wat advies lewer aan die Kommissie en aan ander lidmate en ampsdraers wat daarom vra. Die beperkende siening en benutting van die kerkreg in die Kerk verloop op die lees van die burgerlike reg - dit wil sê, slegs wanneer omstandighede dit verg - terwyl die breër betekenis van die kerkreg, soos verwoord in die kerkorde, en verdere uitleg in die gewone besluite van die Algemene Kerkvergadering dikwels links gelaat word.

Navraag oor die blootstelling wat voornemende studente tydens die teologiese opleiding geniet, dui op 'n redelike onderwaardering van kerkreg aan die Fakulteit Teologie aan die Universiteit van Pretoria, waar studente van die Hervormde Kerk in 'n gesamentlike fakulteit saam met die Nederduitse Gereformeerde Kerk en ander kerklike vennote opgelei word om predikante te word. Tydens 'n gesprek wat op Stellenbosch plaasgevind het op 21 Maart 2018 met twee dosente van die fakulteit, naamlik prof. Johan van der Merwe en dr Wim Dreyer (albei dosente in departement Kerkgeskiedenis en Kerkreg aan die Teologiese Fakulteit van die Universiteit van Pretoria) het dit geblyk dat kerkreg slegs 'n keusevak is en studente nie verplig is om dit te neem nie. Die enigste moontlikheid is dus om deur die Hervormde Teologiese Kollege (HTK), wat aan dieselfde fakulteit vanweë die Hervormde Kerk gevestig is, studente in kerkreg te onderrig.

Die situasie aan die Noordwes-Universiteit, waar studente van die Gereformeerde Kerke van Suid-Afrika (GKSA) opgelei word, is radikaal anders. Daar is 'n voltydse dosent, wat 'n professoraat beklee, verantwoordelik vir kerkreg as 'n nagraadse kursus. Studente word onderlê in die grondbeginsels van die presbiteriale kerkregering, historiese ontwikkeling, die kerkorde prinsipieel gesien, asook praktiese blootstelling, aangebied in ' $n$ module wat drie jaar duur.

Die Skriftuurlike basis van die kerkorde vergroot egter die betekenis en gebruik van die kerkorde tot'n middel waardeur gepoog word om 'n kerklike praktyk na te hou wat in verlenging van die Skrif geleë is. Dus nie 'n stok om mee te slaan nie, maar 'n hulp tot goeie kerklike voortgang (vgl. Noordmans 1984:458).

Dit lei tot die kritieke vraag vir ampsdraers en lidmate: Waarom moet ernstig gepoog word om die kerkorde na te leef wat deur die laaste sinodale (Algemene Kerkvergadering 2016) vergadering vasgestel is? Die antwoord is: Nie ter wille van die regter van die hoogste hof nie (met respek), maar om Jesus wil. Die essensie van 'n kerkorde gesien in die verlenging van die Skrif as primêre bron van die kerkreg en die kerkorde, verwoord 'n bepaalde kerklike praktyk tot die welwese van die kerk wat erns maak met sy Reformatoriese erfenis. Daarom is onderrig in die kerkorde en sy volle betekenis as hermeneutiese agtergrond relevant, sodat die spanning tussen die kerk en sy lidmate aan die een kant en die Skrif as Woord van God aan die ander kant, nie oorspan word en ontaard in 'n kerklike praktyk wat uit die sekulêre wêreld aangeleer is nie.

Kerklike verskille, van watter aard ook al, hoort nie in howe tuis nie - in elk geval nie as erns gemaak word met die kerklike reg as sodanig nie. Die neiging om met kerklike verskille 'n beroep op howe in die burgerlike regspleging te doen, is een van die grofste hedendaagse kerkordelike vergrype. Hier kan ook verwys word na die neiging om oor verskille, van welke aard ook al, gewoon tuis te bly, offergawe te onttrek of na ander gemeentes of kerke te verhuis. Dit is 'n tipiese vakbondmentaliteit wat vreemd aan die kerk is. Hieronder kan die neiging om nie aan die debat tydens veral sinodale vergaderings deel te neem nie en dan in gemeentes 'n eiesinnige weg te volg as protes teen geneemde besluite, eweneens ter sprake gebring word.

Die relevansie van kerkreg is 'n wesenlike aangeleentheid wat teruggryp op die Reformatoriese sola scriptura en uitmond in 'n Christologiese ekklesiologie wat lidmate en ampsdraers motiveer tot 'n kerklike bewussyn wat in Christus alles anders maak, selfs teen alle verwagting in.

\section{Erkenning Mededingende belange}

Die outeur verklaar dat hy geen finansiële of persoonlike verbintenis het met enige party wat hom nadelig kon beïnvloed het in die skryf van hierdie artikel nie.

\section{Literatuurverwysings}

Bakhuizen van den Brink, J.N., De Bruin, C.C. \& Dankbaar, W.F., 1965, Handboek der kerkgeschiedenis, tweede deel, De Middeleeuwen, Bakker/Daamen, Den Haag.

Balke, W. \& Oostenbrink-Evers, H., 1993, De commissie voor de kerkorde (1945-1950), Boekencentrum, Zoetermeer.

Barth, K., 1964, Kirchliche Dogmatik, IV/2, Zürich, EVZ.

Bosch, D., 2005, Transforming mission, Paradigm shifts in theology of mission, American society of missiology series 16 , Orbis, New York.

Bouwman, H., 1985, Gereformeerd Kerkrecht, eerste deel, De Groot Goudriaan, Kampen.

Brecht, M., 1983, Martin Luther, sein Weg zur Reformation, Calwer, Stuttgart.

Bronkhorst, A.J., 1947, Schrift en Kerkorde, Zuid-Holland, den Haag.

Coertzen, P., 1991, Gepas en ordelik, RGN, Pretoria.

Coertzen, P., 2001, 'Die regsposisie van kerke in Suid-Afrika', NGTT 42/1\&2, 115-122.

Coertzen, P., 2002, '350 Jaar Gereformeerd 1652-2002. Kerkreg en kerkregering in die NG Kerk gedurende die afgelope dekades', NGTT 43/3\&4, 376-390.

Deddens, D., 1988, 'Het congregationalisme', in W. van't Spijker \& L.C. van Drimmelen (red.), Inleiding tot de studie van het Kerkrecht, pp. 106-109, Kok, Kampen.

De Jong, O.J., 1987, Geschiedenis der kerk, Callenbach, Nijkerk.

Denzinger, H., 2012, Enchiridion symbolorum definitionem et declarationum de rebus fidei et morum / Compendium of creeds, definitions, and declarations on matters of faith and morals, Ignatius, San Francisco, CA.

De Wet, C.J.H., 1921, Die kollegiale kerkreg, Bottenburg, Amsterdam.

Dingemans, G.J.D., 1988, 'Kerkorde als ecclesiologische vormgeving', in W. van't Spijker, \& W. van Drimmelen, L. C. (red.), Inleiding tot de studie van het Kerkrecht, pp. 207-220, Kok, Kampen.

Dreyer, W.A., 2013, 'Missional ecclesiology as basis for a new church order: A case study', HTS Teologiese/ Theological Studies 69(1), Art. \#1368, 5 pages. https://doi. org/10.4102/hts.v69i1.1368 
Dreyer, W., 2016, 'Heretic or rebel? The heresy trial of Albert Geyser', HTS Teologiese Studies/Theological Studies 72(4), a3745. https://doi.org/10.4102/hts.v72i4.3745

Engelbrecht, S.P., 1953, Geskiedenis van die Nederduitsch Hervormde Kerk van Afrika, HAUM-De Bussy, Kaapstad, Pretoria.

Graafland, C., 1989, Kinderen van één moeder. Calvijns visie op de kerk volgens zijn Institutie, Kok, Kampen.

Hovius, J., 1972, Notities betreffende de Synode te Emden, 1571, en haar artikelen, Apeldoornse Studies 4, Kok, Kampen.

Huysmans, R.G.W., 1988, 'Hoofdlijnen uit het Katholiek Kerkrecht', in W. van't Spijker \& L.C. van Drimmelen (red.), Inleiding tot de studie van het Kerkrecht, pp. 183-195, Kok, Kampen.

Jansen, J., 1952, Korte verklaring van de Kerkorde der Gereformeerde Kerken, Kok, Kampen.

Kersten, G.H., 1980, Kerkelijk handboekje, De Banier, Utrecht.

Koffeman, L.J., 2009, Het goed recht van de kerk, Kok, Kampen.

Kuyper, A., 1884, Tractaat van de reformatie der kerken, Höveker, Amsterdam.

Le Roux du Plooy, A., 2008, "n Kritiese analise van die begrip ratifikasie volgens die Gereformeerde Kerkreg', HTS 64(1), 415-428.

Le Roux du Plooy, A., 2012, 'Die hermeneutiek van gereformeerde kerkreg', In die Skriflig/In Luce Verbi 46(1), Art. \#36, 8 pages. https://doi.org/10.4102/ids. v46i1.36

Nederduitsch Hervormde Kerk van Afrika (NHKA), 2010a, Algemene Kerkvergadering 2010, Besluitebundel, Pretoria.

Nederduitsch Hervormde Kerk van Afrika (NHKA), 2010b, Algemene Kerkvergadering 2010, Kerkorde, Pretoria.

Nederduitsch Hervormde Kerk van Afrika (NHKA), 2013, Algemene Kerkvergadering 2013, Agenda, Pretoria.

Nederduitsch Hervormde Kerk van Afrika (NHKA), 2016, Algemene Kerkvergadering 2016, Kerkorde, Pretoria.

Noordmans, O., 1984, Verzamelde werken, V, Kok, Kampen.

Noordmans, O., 1990, Verzamelde werken, VIII, Kok, Kampen.

Oostenbrink-Evers, H., 2000, Beginselen en achtergrond van de kerkorde van 1951 van de Nederlandse Hervormde Kerk, Boekencentrum, Zoetermeer.

Plomp, J., 1967, Presbyteriaal - episcopaal?, Kok, Kampen.

Plomp, J., 1971, 'De Kerkorde van Emden', in D. Nauta, J.P. Van Doorn \& O.J. De Jong (red.), De Synode van Emden 1571-1971, Kok, Kampen.

Pont, A.D., 1981, Die historiese agtergronde van die kerklike reg, Deel 1, HAUM, Pretoria-Kaapstad.

Pont, A.D., 1991, Die historiese agtergronde van ons kerklike reg, Deel 2, Kital, Pretoria.

Post, J.J.H., 2003, Een sikkel in een vreemde oogst?, Groen, Heerenveen.

Protestantse Kerk Nederland (PKN), 2004, Generale Synode van de Protestantse Kerk in Nederland 2003, Kerkorde en ordinanties, Boekencentrum, Zoetermeer.

Rutgers, F.L., 1980, Acta van de Nederlandsche Synoden der zestiende eeuw, J.P. Van den Tol, Dordrecht.

Schaff, P., 1890, History of the Christian church, complete eight volumes in one, Kindle Edition, Theological Seminary, Mercersburg, PA.
Scholtz, A., 2001, 'Die kerk en die regbank - ' $\mathrm{n}$ nabetragting na aanleiding van die Schreuder-saak', NGTT 42/1\&2, 184-191.

Smit, C.J., 1984, God se orde vir sy kerk, N G Kerkboekhandel, Pretoria.

Smit, C.J., 1995, 'Die kerkregtelike toepassing van die reëls van "natuurlike geregtigheid" op grond van die Skrif', In die Skriflig 29(3), 395-412. https://doi. org/10.4102/ids.v29i3.1547

Smit, J., 2018, 'The decline of reformed church polity in South Africa', In die Skriflig 52(3), a2309. https://doi.org/10.4102/ids.v52i3.2309

Van de Beek, A., 1988, 'Hermeneutiek van het Kerkrecht', in W. van't Spijker \& L.C van Drimmelen (red.), Inleiding tot de studie van het Kerkrecht, pp. 59-72, Kok, Kampen.

Van den Heuvel, P., 1991, De Hervormde kerkorde, een praktische toelichting, Boekencentrum, Zoetermeer.

Van der Linde, G.P.L., 1965, Die grondbeginsels van die presbiteriale kerkregeringstelsel, Pro Rege, Potchefstroom.

Van der Merwe, J.C., 2011, 'Missionale gemeentes in die Nederduitsch Hervormde Kerk van Afrika - Teologies verantwoord', HTS Teologiese Studies/Theological Studies 67(3), Art. \#1094, 9 pages. / https://doi.org/10.4102/hts.v67i3.1094

Van der Walt, J.J., 1976, Christus as Hoof van die kerk en die presbiteriale kerkregering, Pro Rege, Potchefstroom.

Van Ruler, A.A., 1952, Bijzonder en algemeen ambt, Callenbach, Nijkerk.

Van't Spijker, W., 1972, Goddelijk recht en kerkelijke orde by Martin Bucer, Apeldoornse studies, Kok, Kampen.

Van't Spijker, W., 1990a, 'Episcopalisme', in W. van 't Spijker, W. Balke, K. Exalto \& L. van Driel (red.), De Kerk, pp. 301-312, De Groot Goudriaan, Kampen.

Van't Spijker, W., 1990b, 'Congregationalisme' in W. van 't Spijker, W. Balke, K. Exalto \& L. van Driel (red.), De Kerk, pp. 313-325, De Groot Goudriaan, Kampen.

Van't Spijker, W., 1990c, 'Het presbyteriale-synodale stelsel', in W. van 't Spijker, W. Balke, K. Exalto \& L. van Driel (red.), De Kerk, pp. 326-338, De Groot Goudriaan, Kampen.

Van't Spijker, W., 1992, 'Rechtvaardiging en recht in de kerk: Over de theologische achtergronden van het gereformeerde kerkrecht', HTS 48 3\&4, 995-1011. https:// doi.org/10.4102/hts.v48i3/4.2465

Van Wyk, B.J., 1991, Die presbiteriaal-sinodale kerkbegrip, Kital, Pretoria.

Van Wyk, B.J., 2004, 'Die kerkorde en die kerklike reg in die Nederduitsch Hervormde Kerk van Afrika aan die hand van die presbiteriaal-sinodale kerkbegrip', Ongepubliseerde PhD proefskrif, Universiteit van Pretoria.

Van Wyk, B.J., 2008, 'As jou broer verkeerd opgetree het teen jou ...': Enkele aspekte van kerklike dissipline uit die Kerkorde van die Nederduitsch Hervormde Kerk van doi.org/10.4102/hts.v64i3.83

Van Wyk, B.J., 2016, 'Jesus Christus as kefalē en die Gees as arrabōn vir die ekklēsia: ' $n$ eksegeties-hermeneutiese studie', ongepubliseerde PhD proefskrif, NWU.

Van Wyk, B.J., 2017, 'Efesiërs 1:14 en 1:22, 23 as 'n skriftuurlike maksimum-minimum vir die ekklesiologie', HTS Teologiese Studies/Theological Studies 73(1), a4073. https://doi.org/10.4102/hts.v73i1.4073

Vorster, J.M., 1992, 'Kerkreg en Konteks', Studia Historia Ecclesiastica XVIII (1), 87-95. Weijland, H.B., 1988, 'De ontwikkeling van de oud-Christelijke kerkinrichting en de versterking van de episcopale structuren', in W. van't Spijker \& L.C. van Drimmelen (red.), Inleiding tot de studie van het Kerkrecht, pp. 75-85, Kok, Kampen. 